\title{
Anti-inflammatory and anti-cancer activity of mulberry (Morus alba L.) root bark
}

\author{
Hyun Ji Eo ${ }^{1 \dagger}$, Jae Ho Park ${ }^{2 \dagger}$, Gwang Hun Park', Man Hyo Lee ${ }^{3}$, Jeong Rak Lee 3 , Jin Suk Koo ${ }^{1,4}$
} and Jin Boo Jeong ${ }^{1,4,5^{*}}$

\begin{abstract}
Background: Root bark of mulberry (Morus alba L.) has been used in herbal medicine as anti-phlogistic, liver protective, kidney protective, hypotensive, diuretic, anti-cough and analgesic agent. However, the anti-cancer activity and the potential anti-cancer mechanisms of mulberry root bark have not been elucidated. We performed in vitro study to investigate whether mulberry root bark extract (MRBE) shows anti-inflammatory and anti-cancer activity.

Methods: In anti-inflammatory activity, NO was measured using the griess method. iNOS and proteins regulating NF-KB and ERK1/2 signaling were analyzed by Western blot. In anti-cancer activity, cell growth was measured by MTT assay. Cleaved PARP, ATF3 and cyclin D1 were analyzed by Western blot.

Results: In anti-inflammatory effect, MRBE blocked NO production via suppressing iNOS over-expression in LPS-stimulated RAW264.7 cells. In addition, MRBE inhibited NF-KB activation through p65 nuclear translocation via blocking IKB-a degradation and ERK1/2 activation via its hyper-phosphorylation. In anti-cancer activity, MRBE deos-dependently induced cell growth arrest and apoptosis in human colorectal cancer cells, SW480. MRBE treatment to SW480 cells activated ATF3 expression and down-regulated cyclin D1 level. We also observed that MRBE-induced ATF3 expression was dependent on ROS and GSK3 3 . Moreover, MRBE-induced cyclin D1 down-regulation was mediated from cyclin D1 proteasomal degradation, which was dependent on ROS.
\end{abstract}

Conclusions: These findings suggest that mulberry root bark exerts anti-inflammatory and anti-cancer activity.

Keywords: Morus alba L. Mulberry root bark, Medicinal plant, Anti-inflammation, Anti-cancer

\section{Background}

Inflammation is an innate immune response by various immune cells including macrophages for the protection against the harmful stimuli such as virus and bacteria [1]. As a consequence of excessive inflammatory response, large amounts inflammatory mediators, such as nitric oxide (NO) and prostaglandin $\mathrm{E}_{2}\left(\mathrm{PGE}_{2}\right)$ are produced [2]. Inflammatory mediators-induced chronic inflammation is considered to be a cause of numerous human diseases including cancer, atherosclerosis, arthritis and septic shock [3-5]. Among inflammatory mediators, NO is produced by inducible nitric oxide synthase (iNOS) and results in

\footnotetext{
* Correspondence: jjb0403@anu.ac.kr

${ }^{\dagger}$ Equal contributors

${ }^{1}$ Department of Bioresource Sciences, Andong National University, Andong

760749, South Korea

${ }^{4}$ Insititute of Agricultural Science and Technology, Andong National

University, Andong 760380, South Korea

Full list of author information is available at the end of the article
}

many disease processes such as carcinogenesis, obesity and diabetes [6-8]. iNOS in macrophage is activated following infection. Therefore, iNOS-mediated NO is a ubiquitous mediator of a wide range of inflammatory conditions and reflects degree of inflammation, thus providing a measure of the inflammatory process [9].

It has been reported that development of cancer is associated with inflammation $[10,11]$. Cancer is a major problem of public health in USA with the estimated 1.6 million new cancer cases and 5.8 hundred thousand cancer deaths occur in USA in 2013 [12]. Among inflammation-induced cancers, colorectal cancer is the third leading cause of cancer-related morbidity and mortality in USA [12]. Recently, cancer chemoprevention has received a great attention and medicinal plants have been regarded as effective anti-cancer sources [13].

Root bark of mulberry (Morus alba L.) has been used in herbal medicine as anti-phlogistic, liver protective, kidney 
protective, hypotensive, diuretic, anti-cough and analgesic agent [14]. However, the anti-cancer activity and the potential anti-cancer mechanisms of mulberry root bark have not been elucidated.

Activating transcription factor 3 (ATF3) is a member of the ATF/CREB subfamily of the basic-region leucine zipper (bZIP) family. In human colorectal cancer, ATF3 expression was suppressed compared to normal adjacent tissue [15]. Up-regulation of ATF3 expression can induce apoptosis in colorectal cancer cells. In addition, ATF3 induces p53 activation [16,17] and inhibits Ras-mediated carcinogenesis and cyclin D1 expression [18]. Cyclin D1 regulates cell cycle transition from $\mathrm{G} 1$ to $\mathrm{S}$ phase by forming cyclin-dependent kinase (CDK) 4 and 6 [19]. Cyclin D1 overexpression was observed in $68.3 \%$ of human colorectal cancer [20]. Thus, up-regulation of ATF3 and down-regulation of cyclin D1 are major molecular targets for treatment of colorectal cancer.

In light of the therapeutic potential of mulberry root bark in inflammation-induced colorectal cancer, this study was performed to elucidate the biological mechanism by which mulberry root bark inhibits an inflammatory response in LPS-stimulated RAW264.7 cells and induces the inhibition of cell growth and apoptosis in human colorectal cancer cells. Here, for the first time, we reported that mulberry root bark extracts attenuated NO production by suppressing iNOS expression via regulating the activations of NF- $\mathrm{KB}$ and ERK1/2. In addition, it induced cell growth arrest and apoptosis by activating ATF3 expression and cyclin D1 proteasomal degradation in colorectal cancer cells, SW480.

\section{Methods}

\section{Materials}

Cell culture media, Dulbecco's Modified Eagle medium (DMEM) was purchased from Gibco Inc. (NY, USA). LPS (Escherichia coli 055:B5) and 3-(4,5-dimethylthiazol-2-yl)2.5-diphenyltetrazolium bromide (MTT) were purchased from Sigma-Aldrich (St. Louis, MO, USA). SB203580, PD98059 were purchased from Calbiochem (San Diego, CA). SB216763 and N-Acetyl Cysteine (NAC) were purchased from Sigma-Aldrich. Antibodies against iNOS, ATF3 and cyclin D1 were purchased from Santa Cruz Biotechnology, Inc (Santa Cruz, CA, USA). Other antibodies against IKB-a, p65, ERK1/2, phospho-ERK1/2 (Thr202/Tyr204) and b-actin were purchased from Cell Signaling (Bervely, MA, USA). All chemicals were purchased from Sigma-Aldrich, unless otherwise specified.

\section{Sample preparation}

The plant sample, Mulberry (Morus alba L. voucher number: PARK1002(ANH)) root bark, was kindly provided by the Bonghwa Alpine Medicinal Plant Experiment Station, Korea. One kilogram of mulberry root bark was extracted with $1000 \mathrm{ml}$ of $80 \%$ methanol with shaking for $24 \mathrm{~h}$. After $24 \mathrm{~h}$, the methanol-soluble fraction was filtered and concentrated to approximately $20 \mathrm{ml}$ volume using a vacuum evaporator and then fractioned with petroleum ether and ethyl acetate in a separating funnel. The ethyl acetate fraction was separated from the mixture, evaporated by a vacuum evaporator, and prepared aseptically and kept in a refrigerator until use.

\section{Cell culture and treatment}

Mouse macrophage cell line, RAW264.7 and human colorectal cancer cell line, SW480 were purchased from Korean Cell Line Bank (Seoul, Korea) and grown in DMEM supplemented with $10 \%$ fetal bovine serum (FBS), $100 \mathrm{U} / \mathrm{ml}$ penicillin, and $100 \mu \mathrm{g} / \mathrm{ml}$ streptomycin. These cells were maintained at $37^{\circ} \mathrm{C}$ under a humidified atmosphere of $5 \% \mathrm{CO}_{2}$. Mulberry root bark extracts (MRBE) were dissolved in dimethyl sulfoxide (DMSO) and then treated to cells. DMSO was used as a vehicle and the final DMSO concentration was not exceeded $0.1 \%(\mathrm{v} / \mathrm{v})$.

\section{Measurement of nitric oxide (NO) production}

Inhibitory effect of mulberry root bark extracts on the production of NO in LPS-stimulated RAW264.7 cells was evaluated using literature [21]. Briefly, RAW264.7 cells were plated in 12-well plate for overnight. Cells were pre-treated with mulberry root bark extracts at the indicated concentrations for $2 \mathrm{~h}$ and then co-treat with LPS $(1 \mu \mathrm{g} / \mathrm{ml})$ for the additional $18 \mathrm{~h}$. After $18 \mathrm{~h}, 200 \mu \mathrm{l}$ of the media was mixed with equal amount of Griess reagent (1\% sulfanilamide and 0.1\% N-1-(naphthyl) ethylenediaminediHCl in $2.5 \% \mathrm{H}_{3} \mathrm{PO}_{4}$ ). The mixture was incubated for the additional $5 \mathrm{~min}$ at the room temperature and the absorbance was measured at $540 \mathrm{~nm}$.

\section{Isolation of cytosol and nuclear fraction}

Nuclear and cytosolic fractions were prepared following the manufacturer's protocols of nuclear extract kit (Active Motif, Carlsbad, CA, USA). Briefly, RAW264.7 cells were washed with ice-cold PBS containing phosphatase inhibitors and harvested with 1xhypotonic buffer for $15 \mathrm{~min}$ at $4^{\circ} \mathrm{C}$. After adding detergent, the cells were centrifuged at $15,000 \mathrm{rpm}$ for $30 \mathrm{~min}$ and then the supernatants were collected as cytoplasmic fraction. Nuclear fractions were collected by suspending nuclear pellet with lysis buffer and centrifugation.

\section{MTT assay}

The 3-(4,5-dimethylthizaol-2-yl)-2,5-diphenyl tetrazolium bromide (MTT) assay was used to measure cell proliferation. Briefly, SW480 cells were seeded onto 96-well culture plate at a density of 50,000 cells per well. The cells were treated with MRBE for $24 \mathrm{~h}$. Then, $50 \mu \mathrm{l}$ of MTT solution $(1 \mathrm{mg} / \mathrm{ml})$ was added to each well. The resulting 
crystals were dissolved in DMSO. The formation of formazan was measured by reading absorbance at a wavelength of $570 \mathrm{~nm}$.

\section{SDS-PAGE and Western blot}

Cells were washed with $1 \times$ phosphate-buffered saline (PBS), and lysed in radioimmunoprecipitation assay (RIPA) buffer (Boston Bio Products, Ashland, MA, USA) supplemented with protease inhibitor cocktail (Sigma Aldrich) and phosphatase inhibitor cocktail (Sigma Aldrich), and centrifuged at $12,000 \times \mathrm{g}$ for $10 \mathrm{~min}$ at $4^{\circ} \mathrm{C}$. Protein concentration was determined by the bicinchoninic acid (BCA) protein assay (Pierce, Rockford, IL, USA) using bovine serum albumin (BSA) as the standard. The proteins were separated on SDS-PAGE and transferred to PVDF membrane (Bio-Rad Laboratories, Inc., Hercules, CA, USA). The membranes were blocked for non-specific binding with 5\% nonfat dry milk in Tris-buffered saline containing 0.05\% Tween 20 (TBS-T) for $1 \mathrm{~h}$ at room temperature and then incubated with specific primary antibodies in 5\% nonfat dry milk at $4^{\circ} \mathrm{C}$ overnight. After three washes with TBS-T, the blots were incubated with horse radish peroxidase (HRP)-conjugated immunoglobulin $\mathrm{G}$ (IgG) for $1 \mathrm{~h}$ at room temperature and chemiluminescence was detected with ECL Western blotting substrate (Amersham Biosciences) and visualized in Polaroid film.

Reverse transcriptase-polymerase chain reaction (RT-PCR) Total RNA was prepared using a RNeasy Mini Kit (Qiagen, Valencia, CA, USA) and total RNA $(1 \mu \mathrm{g})$ was revese-transcribed using a Verso cDNA Kit (Thermo Scientific, Pittsburgh, PA, USA) according to the manufacturer's protocol for cDNA synthesis. PCR was carried out using PCR Master Mix Kit (Promega, Madison, WI, USA) with primers for human ATF3, human cyclin D1 and human GAPDH as follows: human ATF3: 5' -gtttgaggatttt gctaacctgac-3', and reverse $5^{\prime}$-agctgcaatcttatttctttctcgt- $3^{\prime}$; human cyclin D1: forward 5'-aactacctggaccgcttcct-3' and reverse 5 '-ccacttgagcttgttcacca-3' ; huaman GAPDH: forward 5 '-acccagaagactgtggatgg- $3^{\prime}$ and reverse $5{ }^{\prime}$ ttctagacggcaggtcaggt-3'.

\section{Statistical analysis}

Statistical analysis was performed with the Student's unpaired t-test, with statistical significance set at *, $\mathrm{P}<0.05$.

\section{Results}

The effect of MRBE on NO production and iNOS expression in LPS-stimulated RAW264.7 cells

Macrophages play an important role in inflammatory response by producing inflammatory mediators such as NO, $\mathrm{PGE}_{2}$ and TNF- $\alpha$ [22]. So, we used the mouse macrophage cell line RAW264.7 cells for evaluating anti-inflammatory effect of MRBE. iNOS-mediated NO is associated with cytotoxicity and tissue damage and involved in several processes such as chronic inflammation and immunoregulation [23]. To determine if MRBE could reduce NO generation by LPS, RAW264.7 cells were pretreated with MRBE for $2 \mathrm{~h}$ and then co-treated with LPS $(1 \mu \mathrm{g} / \mathrm{ml})$ for the additional $18 \mathrm{~h}$. As shown in Figure 1A, treatment of LPS without MRBE induced NO overproduction in LPS-stimulated RAW264.7 cells, while pretreatment of MRBE suppressed LPS-mediated NO overproduction. Since NO production is regulated by iNOS expression, the effect of MRBE on iNOS expression was evaluated by Western blot. As shown in Figure 1B, LPS overexpression was detected in the cells stimulated LPS alone. However, MRBE inhibited iNOS expression in LPS-stimulated RAW264.7 cells. From these results, MRBE-induced decrease of NO production may result from the inhibition of LPS-induced iNOS overexpression in RAW264.7 cells.

\section{Inhibitory effect of MRBE on LPS-induced NF-KB and ERK1/2 activation in RAW264.7 cells}

To elucidate the effect of MRBE on NF- $k B$ activation, we performed a Western blot for ІкB- $\alpha$ degradation in LPS-stimulated RAW264.7 cells. As shown in Figure 2A, LPS induced IKB- $\alpha$ degradation at $15 \mathrm{~min}$ after the stimulation. However, pretreatment of MRBE attenuated IкB- $\alpha$ degradation in a dose-dependent manner. p65 nuclear translocation resulted from IKB- $\alpha$ degradation are essential in NF- $\mathrm{B}$ activation. Thus we examined whether MRBE inhibits p65 nuclear translocation. As shown in Figure 2B, LPS markedly increased an amount of p65 in the nucleus of RAW264.7 cells. However, pretreatment of MRBE dosedependently inhibited LPS-induced p65 nuclear translocation in RAW264.7 cells. There is a growing evidence that NF- $\mathrm{BB}$ activation is modulated by ERK1/2 activation [24]. Thus, we evaluated the effects of MRBE on phosphorylation of ERK1/2 in LPS-stimulated RAW264.7 cells using Western blot to further investigate whether inhibition of NF- $\mathrm{kB}$ activation by MRBE was associated with modulation of ERK1/2. As shown in Figure 2C, Increase of phosphorylation of ERK1/2 was observed in LPS-stimulated RAW264.7 cells without MRBE. However, MRBE attenuated LPS-induced ERK1/2 phosphorylation. Overall, these results suggest that MRBE may inhibit the inflammatory response by ERK1/2-mediated NF-kB activation in LPSstimulated RAW264.7 cells.

\section{Effect of MRBE on cell viability and apoptosis in human colorectal cancer cell line, SW480}

There are a number of evidences indicating that MRBE shows anticancer activity in human leukemia cells $[25,26]$. To observe whether MRBE affects viability and apoptosis in human colorectal cancer cell line, SW480, we carried out MTT assay for cell viability and Western blot for apoptosis. As shown in Figure 3A, treatment of MRBE 


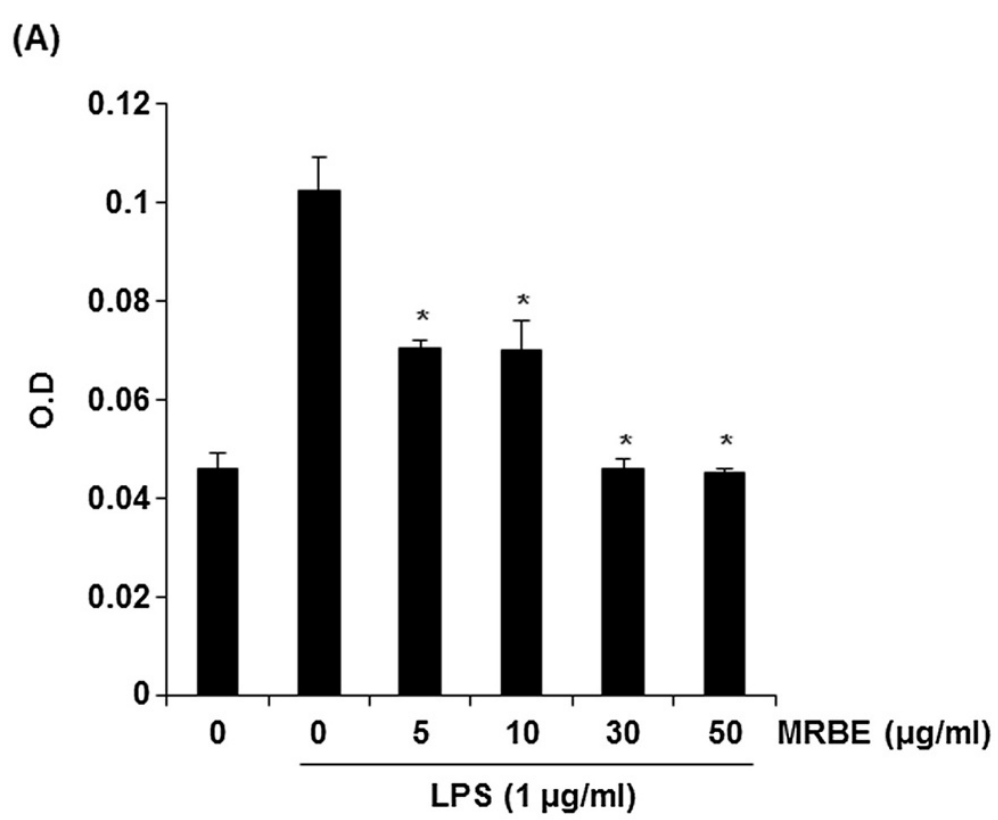

(B)

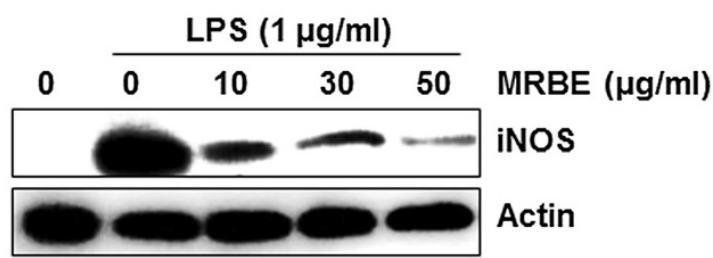

Figure 1 Effect of MRBE on NO production (A) and iNOS (B) in LPS-stimulated RAW264.7 cells. RAW264.7 cells were pre-treated with MRBE at the indicated concentrations for $2 \mathrm{~h}$ and then co-treated with LPS $(1 \mu \mathrm{g} / \mathrm{ml})$ for the additional $18 \mathrm{~h}$. After treatment, NO production was measured using the media and Griess reagent and cell lysates were resolved by SDS-PAGE, transferred to PVDF membrane, and probed with iNOS antibody for Western blot. iNOS protein was visualized using ECL detection. Actin was used as internal control. DMSO was used as a vehicle. Values given are the mean \pm SD $(n=3) .{ }^{*} p<0.05$ compared to LPS treatment without MRBE.

dose-dependently reduced the viability of SW480 cells by $43 \%, 71 \%$ and $83 \%$ at $6.25 \mu \mathrm{g} / \mathrm{ml}, 12.5 \mu \mathrm{g} / \mathrm{ml}$ and $25 \mu \mathrm{g} / \mathrm{ml}$, respectively. Apoptosis was also induced by MRBE treatment (Figure 3B).

\section{Effect of MRBE on the levels of ATF3 and cyclin D1 in protein and mRNA in SW480 cells}

There is growing evidence that activating transcription factor 3 (ATF3) is linked to cell growth arrest and apoptosis in colorectal cancer. To investigate whether MRBE activates ATF3 expression in human colorectal cancer cells, SW480 cells were treated with MRBE at the indicated concentrations for $24 \mathrm{~h}$. As shown in Figure $4 \mathrm{~A}$ and $4 \mathrm{C}, \mathrm{MRBE}$ induced ATF3 expression in the levels of both protein and mRNA. Time-course experiment showed that induction of ATF3 by MRBE occurred after $1 \mathrm{~h}$ stimulation (Figure 4D).

We also evaluated whether MRBE regulates cyclin D1 level in SW480 cells since cyclin D1 is associated with cell growth arrest and apoptosis. As shown in Figure 4B,
MRBE decreased the protein level of cyclin D1 in a dose-dependent manner. However, decrease in mRNA level of cyclin D1 by MRBE treatment was not observed (Figure 4C). In time-course experiment for cyclin D1 (Figure 4D), MRBE significantly reduced cyclin D1 protein level after $1 \mathrm{~h}$ stimulation.

\section{GSK3 $\beta$ and ROS-dependent ATF3 activation of MRBE in SW480 cells}

To elucidate the molecular mechanism for MRBE-induced ATF3 expression, we evaluated several signaling pathways affected by MRBE. SW480 cells were pretreated with kinase inhibitors such as PD98059 (ERK1/2 inhibitor), SB203580 (p38 inhibitor) and SB216763 (GSK-3 $\beta$ inhibitor), and NAC (ROS scavenger) for $2 \mathrm{~h}$ prior to incubation with $25 \mu \mathrm{g} / \mathrm{ml}$ of MRBE. As shown in Figure 5A, MRBE-induced ATF3 expression was observed in the cells pretreated with PD98059 and SB203580. However, pretreatments of SB216763 and NAC diminished MRBE-induced ATF3 expression 
(A)

\begin{tabular}{|c|c|c|c|c|c|}
\hline \multirow[b]{2}{*}{0} & \multicolumn{4}{|c|}{ LPS $(1 \mu \mathrm{g} / \mathrm{ml})$} & \multirow{3}{*}{$\begin{array}{l}\text { MRBE }(\mu \mathrm{g} / \mathrm{ml}) \\
\text { IKB- } \alpha\end{array}$} \\
\hline & 0 & 5 & 10 & 30 & \\
\hline & & & & & \\
\hline & 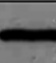 & & & & Actin \\
\hline
\end{tabular}

(B)

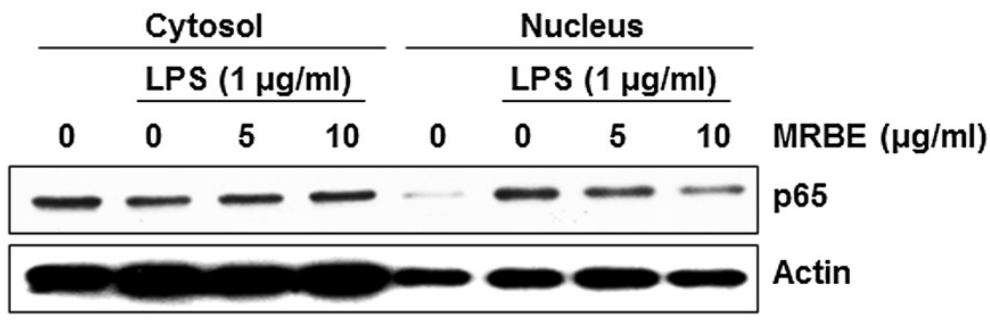

(C)

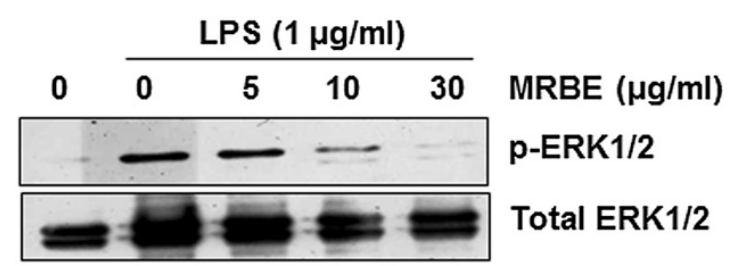

Figure 2 Effect of MRBE on IKB-a degradation (A), p65 nuclear translocation (B) and ERK1/2 phosphorylation (C) in LPS-stimulated RAW264.7 cells. RAW264.7 cells were pre-treated with MRBE at the indicated concentrations for $2 \mathrm{~h}$ and then co-treated with ( $1 \mu \mathrm{g} / \mathrm{ml})$ for $15 \mathrm{~min}$ (for Western blot of IKB-a and ERK1/2 phosphorylation) or $30 \mathrm{~min}$ (for Western blot of p65). DMSO was used as a vehicle. Cell lysate were resolved by SDS-PAGE, transferred to PVDF membrane, and probed with antibodies against IKB-a, p-ERK1/2, total ERK1/2 and p65. The proteins were then visualized using ECL detection. Actin was used as an internal control.

(Figure 5B). Collectively, these results suggest the pathways of GSK-3 $\beta$ and ROS may be involved in MRBE-induced ATF3 expression.

\section{ROS-dependent cyclin D1 proteasomal degradation by MRBE in SW480 cells}

We found that MRBE dose-dependently attenuated cyclin D1 protein level whiles it did not affect cyclin D1 mRNA level (Figure 4B and 4C). Thus, we asked whether cyclin D1 protein stability was affected by MRBE treatment. Figure 5C shows that MG-132, a well-known proteasome inhibitor, completely blocked MRBE-induced cyclin D1 down-regulation. This result suggests that MRBE-induced cyclin D1 down-regulation may result from proteasomal degradation. SW480 cells were pretreated with kinase inhibitors such as PD98059, SB203580, SB216763 and NAC for $2 \mathrm{~h}$, and then co-treated with $25 \mu \mathrm{g} / \mathrm{ml}$ of MRBE for the additional $1 \mathrm{~h}$ to elucidate the molecular mechanism for cyclin D1 proteasomal degradation affected by MRBE. As shown in Figure 5D and 5E, MRBE-induced cyclin D1 down-regulation was observed in the cells pretreated with PD98059, SB203580 and SB216763. However, NAC attenuated cyclin D1 down-regulation by MRBE. These findings suggest that MRBE induced ROS-dependent cyclin D1 proteasomal degradation.

\section{Discussion}

Although controlled inflammatory response is beneficial to defend and protect the body from harmful factors such as physical damage, precursor chemicals and microbial invasion, inflammation can induce adverse effects such as cancer, atherosclerosis, arthritis and septic shock on the body if the regulation of inflammation is dysfunctional [27]. Since inflammation is associated with many inflammatory mediators such and pathways that lead to a wide range of changes in pathology, it is difficult to treat inflammation [27]. Non-steroidal anti-inflammatory drugs (NSAIDs) have long been used for the treatment of inflammation. However, recently, because of side effects of NSAIDs, herbal medicinal plants have received a great attention and a large number of mechanistic studies have been reported.

Nitric oxide (NO) plays an important role in inflammation pathogenesis [28]. Although NO has an antiinflammatory effect under controlled inflammatory response, it induces chronic inflammation due to overproduction under abnormal regulation [28]. In addition, 


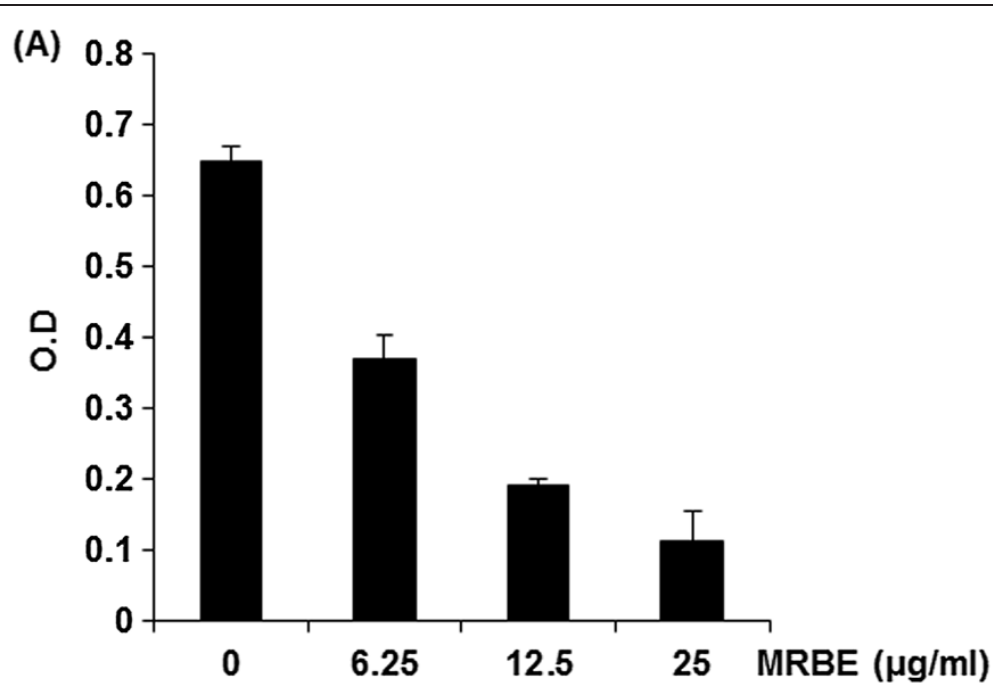

(B)

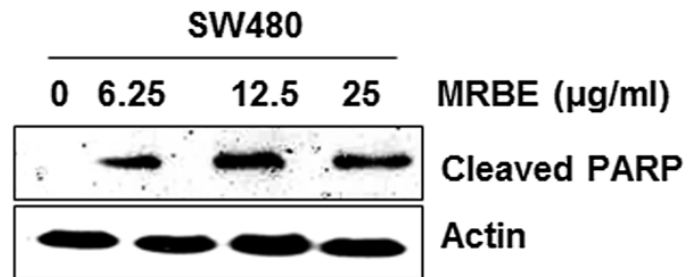

Figure 3 Effect of MRBE on cell growth (A) and apoptosis (B) in SW480 cells. SW480 cells were treated with MRBE at the indicated concentration for $24 \mathrm{~h}$. Cell growth was measured sung MTT solution and expressed as absorbance $\left(A_{570}\right)$. ${ }^{*} P<0.05$ compared to cell without MRBE treatment. Apoptosis by MRBE was evaluated with Western blot against cleaved PARP. Actin was used as an internal control. DMSO was used as a vehicle.

(A)

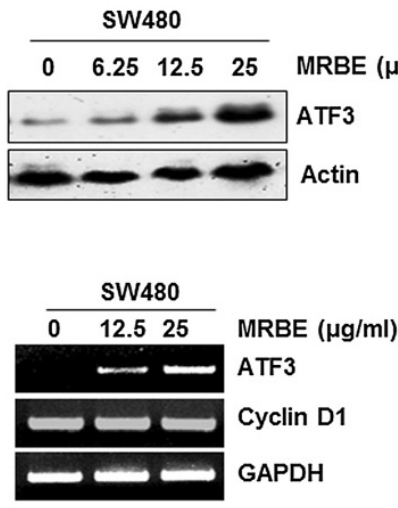

(B)

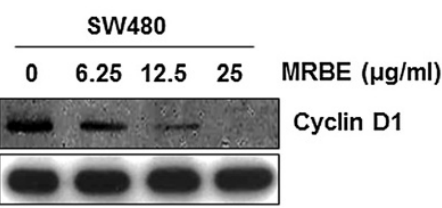

(D)

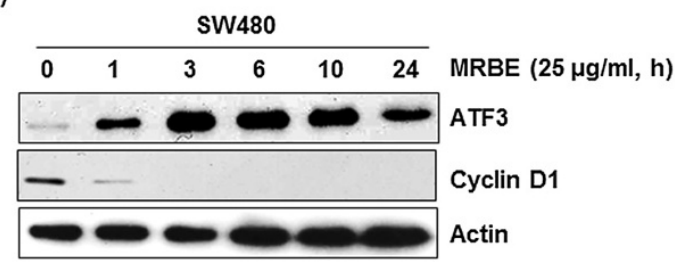

Figure 4 Effects of MRBE on ATF3 and cyclin D1 expression in mRNA and protein level in SW480 cells. (A, B) SW480 cells were treated with MRBE at the indicated concentrations for $24 \mathrm{~h}$. Cell lysates were subjected to SDS-PAGE and the Western blot was performed using antibodies against cyclin D1, ATF3 and actin. For RT-PCR analysis of ATF3 and cyclin D1 gene expression (C), total RNA was prepared after MRBE treatment for 24 h. (D) SW480 cells were treated with MRBE $(25 \mu \mathrm{g} / \mathrm{ml})$ for the indicated times. Cell lysates were subjected to SDS-PAGE and the Western blot was performed using antibodies against cyclin D1, ATF3 and actin. Actin and GAPDH were used as internal control for Western blot and RT-PCR, respectively. DMSO was used as a vehicle. 


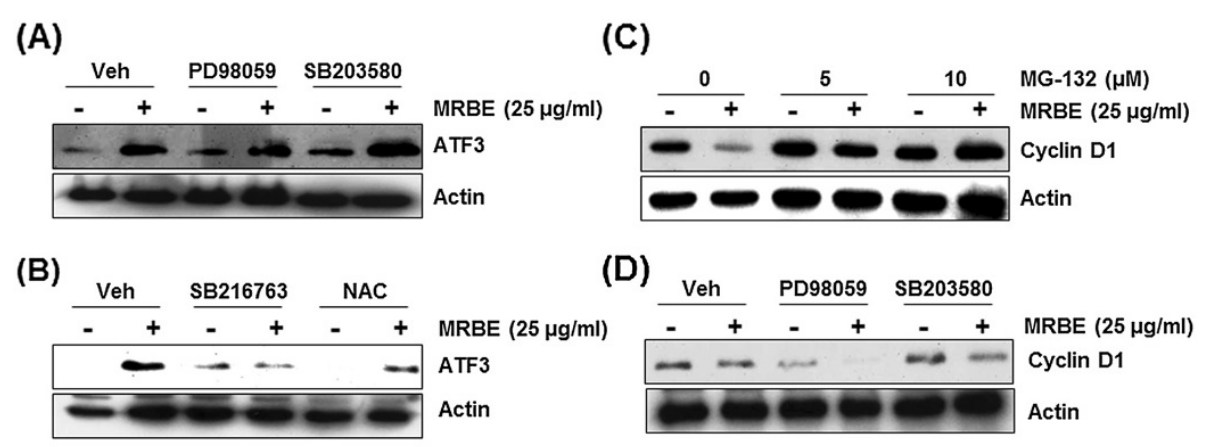

(E)

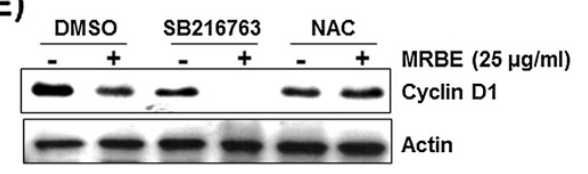

Figure 5 ROS/GSK3 3 -dependent ATF3 expression and ROS-dependent cyclin D1 proteasomal degradation by MRBE. (A, B) SW480 cells

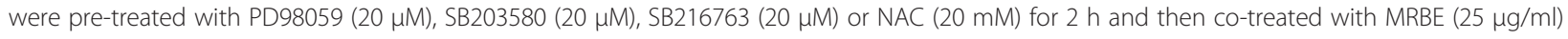
for $1 \mathrm{~h}$. Cell lysates were subjected to SDS-PAGE and the Western blot was performed using antibodies against ATF3 and actin. (C, D, E) SW480 cells were pre-treated with MG132 (5 and $10 \mu \mathrm{M})$, PD98059 $(20 \mu \mathrm{M})$, SB203580 $(20 \mu \mathrm{M})$, SB216763 $(20 \mu \mathrm{M})$ or NAC $(20 \mathrm{mM})$ for $2 \mathrm{~h}$ and then co-treated with MRBE $(25 \mu \mathrm{g} / \mathrm{ml})$ for $1 \mathrm{~h}$. Cell lysates were subjected to SDS-PAGE and the Western blot was performed using antibodies against cyclin D1 and actin. Actin was used as an internal control and DMSO was used as a vehicle.

$\mathrm{NO}$ is involved in inflammation-induced human diseases such as cancer, rheumatoid arthritis, diabetes, septic shock and cardiovascular diseases [29,30]. Therefore, NO is a key target for managing inflammatory diseases. $\mathrm{NO}$ is synthesized by nitric oxide synthases (NOSs) from the amino acid 1-arginine [31,32]. Among three types NOS isoforms including neuronal NOS (nNOS), endothelial NOS (eNOS) and inducible NOS (iNOS), only iNOS is overexpressed in LPS-stimulated macrophage and subsequently generates NO [33]. Mulberry root bark extracts (MRBE) attenuated the over-production of $\mathrm{NO}$ by suppressing LPS-induced iNOS over-expression in RAW264.7 cells. These results suggest that MRBE may exert an anti-inflammatory effect.

There are growing evidences that several agents inhibiting $\mathrm{NO}$ production have been shown to suppress NF-kB activation [34-37]. NF- $\mathrm{kB}$ regulates expression of various genes associated with apoptosis, proliferation, cancer progression and inflammation [38]. In inflammatory response under the external stimuli such as LPS, Activated IkB- $\alpha$ kinase (IKK) phosphorylates IkB- $\alpha$. Phosphorylated IkB- $\alpha$ is subsequently ubiquitinated and degraded by the $26 \mathrm{~S}$ proteasome, which thereby releases NF- $\mathrm{kB}$ from the cytoplasmic NF- $\kappa \mathrm{B}-\mathrm{I} \kappa \mathrm{B} \alpha$ complex and results in NF- $\mathrm{B}$ nuclear translocation. Translocated NF- $\mathrm{kB}$ activates the expressions of target genes associated with inflammation such as iNOS. Thus, NF- $\mathrm{kB}$ is the key transcription factor inducing inflammatory response and a promising target for anti-inflammation [39,40]. In present study, we demonstrated that MRBE inhibits the nuclear translocation of
NF-кB p65 via blocking LPS-induced IкB- $\alpha$ degradation in RAW264.7 cells.

In addition, some agents inhibiting NO production and NF- $\mathrm{kB}$ activation also suppressed the activation of mitogenactivated protein kinases (MAPKs) [37]. The activation of JNK, p38 and ERK1/2 protein regulates iNOS expression and modulates NF-kB activity [41]. We found that MRBE inhibits phosphorylation of ERK1/2 induced by LPS in RAW264.7 cells. These results suggest that inhibition of NF- $\kappa \mathrm{B}$ and ERK pathway is a potential mechanism by which MRBE exerts anti-inflammatory activity.

The connection between inflammation and the development of colorectal cancer is well-established [42]. Thus, we evaluated whether MRBE possesses anti-cancer activity and elucidated its potential mechanisms in human colorectal cancer cells, SW480.

ATF3 has been known as a stress-responsive product [43]. There are growing evidences that the ATF3 expression was repressed in normal cells but might be rapidly induced by various pathological stimuli $[44,45]$. Moreover, ATF3 expression plays an important role in apoptosis induced by a variety of anti-cancer compounds such as berberine [46], conjugated linoleic acid [47], curcumin [48] and 3,3'-diindolylmethane [49] in human colorectal cancer cells, which indicates that ATF3 could function as a pro-apoptotic mediator. We found that MRBE induced cell growth arrest and apoptosis, and activated ATF3 expression in the levels of mRNA and protein in SW480. We also found that MRBE-activated ATF3 expression was reduced by the treatments SB216763 (GSK3 $\beta$ inhibitor) 
and NAC (ROS scavenger), which indicates that MRBEinduced ATF3 expression could be dependent on GSK3 $\beta$ and ROS. Indeed, there is a report that ROS induced ATF3-mediated apoptosis in human colorectal cancer cells [50]. However, the effect of GSK3 $\beta$ on ATF3 expression has not been elucidated. Thus, it is necessary that MRBEinduced ATF3 is affected by GSK3 $\beta$ directly or indirectly. These results suggest that MRBE could induce apoptosis through GSK3 $\beta$ and ROS-dependent ATF3 activation.

Moreover, we observed that MRBE treatment downregulated cyclin D1 protein level but not mRNA in SW480 cells. Thus, we hypothesized that MRBE-induced decrease in cyclin D1 level may be mediated from its proteasomal degradation, and found that pretreatment of MG132 (proteasome inhibitor) suppresses MRBE-induced cyclin D1 down-regulation. There are some kinases reported to degrade cyclin D1 such as p38 [51], ERK1/2 [52], GSK3 $\beta$ [53] and ROS [54]. From using kinase inhibitor, we conclude that MRBE-induced cyclin D1 degradation requires ROS; however, p38, ERK1/2 and GSK3 $\beta$ are not involved in MRBE-induced cyclin D1 degradation. Because cyclin D1 is a well-known cell cycle regulatory protein, MRBE-induced cell growth arrest could be mediated from cyclin D1 proteasomal degradation.

Mulberry root bark has been reported to have various active components such as mulberroside A, oxyresveratrol, mulberrofuran G, kuwanon C, kuwanon G, kuwanon $\mathrm{H}$ and morusin. Among these active components, kuwanon $\mathrm{C}$ and kuwanon $\mathrm{G}$ possess an anti-inflammatory effect [55,56]. In anti-cancer activity, morusin induce apoptosis and suppress NF-kB in human colorectal cancer cells [57]. From these studies, anti-inflammatory and anti-cancer activity by MRBE may be contributed by kuwanon C, kuwanon G or morusin. But, we do not exclude the possibility that other active components could also mediate an anti-inflammatory and anti-cancer activity.

\section{Conclusions}

Taken together, our report is the first to show that MRBE exerts anti-inflammatory and anti-cancer activity. Antiinflammatory effect of MRBE is mediated from inhibiting NF- $\mathrm{KB}$ and ERK $1 / 2$ activation. Anti-cancer activity of MRBE is associated with ROS-dependent cyclin D1 proteasomal degradation and ROS/ GSK3 $\beta$-dependent ATF3 expression.

\section{Abbreviations}

MRBE: Mulberry root bark extract; NO: Nitric oxide; iNOS: Inducible nitric oxide synthease; NF-kB: Nuclear factor-kappaB; ERK1/2: Extracellular signal-related kinase 1/2; ATF3: Activating transcription factor 3; ROS: Reactive oxygen species.

\section{Competing interes}

The authors declare that they have no conflict interest.

\section{Authors' contributions}

JBJ directed and HJE designed the study. HJE, JHP, GHP, MHL, JRL and JSK performed the experiments. HJE and JHP drafted manuscript. JHP, GHP, MHL,
JRL, JSK and JBJ corrected the manuscript. All authors read and approved the final manuscript.

\section{Acknowledgement}

This study was supported by the BK21 PLUS program of Ministry of Education and by Bio-industry Technology Development Program (112144-02-2-SB010), Ministry of Agriculture, Food and Rural Affairs.

\section{Author details}

'Department of Bioresource Sciences, Andong National University, Andong 760749 , South Korea. ${ }^{2}$ Department of Medicinal Plant Science, Jungwon University, Goesan 367805, South Korea. ${ }^{3}$ Gyeongbuk Institute for Bio-industry, Andong 760380, South Korea. ${ }^{4}$ Insititute of Agricultural Science and Technology, Andong National University, Andong 760380, South Korea. ${ }^{5}$ Department of Medicinal Plant Resources, Andong National University, Andong 760380, South Korea.

Received: 12 March 2014 Accepted: 23 June 2014

Published: 25 June 2014

\section{References}

1. Nagata M: Inflammatory cells and oxygen radicals. Curr Drug Targets Inflamm Allergy 2005, 4(4):503-504.

2. Lee YG, Lee WM, Kim JY, Lee JY, Lee IK, Yun BS, Rhee MH, Cho JY: Src kinase-targeted anti-inflammatory activity of davallialactone from Inonotus xeranticus in lipopolysaccharide-activated RAW264.7 cells. Br J Pharm 2008, 154(4):852-863.

3. Ferencik M, Stvrtinova V, Hulin I, Novak M: Inflammation-a lifelong companion. Attempt at a non-analytical holistic view. Folia Microbiologica 2007, 52(2):159-173

4. Hogg N: Free radicals in disease. Semin Reprod Endocrinol 1998, 16(4):241-248.

5. Kim HY, Goo JH, Joo YA, Lee HY, Lee SM, Oh CT, Ahn SM, Kim NH, Hwang JS: Impact on inflammation and recovery of skin barrier by nordihydroguaiaretic Acid as a protease-activated receptor 2 antagonist. Biomol Ther 2012, 20(5):463-469.

6. Mordan $\sqcup$, Burnett TS, Zhang LX, Tom J, Cooney RV: Inhibitors of endogenous nitrogen oxide formation block the promotion of neoplastic transformation in C3H 10 T1/2 fibroblasts. Carcinogenesis 1993, 14(8):1555-1559.

7. Ohshima H, Bartsch $\mathrm{H}$ : Chronic infections and inflammatory processes as cancer risk factors: possible role of nitric oxide in carcinogenesis. Mutat Res 1994, 305(2):253-264.

8. Kroncke KD, Fehsel K, Kolb-Bachofen V: Inducible nitric oxide synthase in human diseases. Clin Exp Immunol 1998, 113(2):147-156.

9. Kwon OK, Lee MY, Yuk JE, Oh SR, Chin YW, Lee HK, Ahn KS: Anti-inflammatory effects of methanol extracts of the root of Lilium lancifolium on LPS-stimulated Raw264.7 cells. J Ethnopharmacol 2010, 130(1):28-34.

10. Balkwill F, Mantovani A: Inflammation and cancer: back to Virchow? Lancet 2001, 357(9255):539-545

11. Coussens LM, Werb Z: Inflammation and cancer. Nature 2002, 420(6917):860-867.

12. Siegel R, Naishadham D, Jemal A: Cancer statistics, 2013. CA-Cancer J Clin 2013, 63(1):11-30.

13. Wang S, Wu X, Tan M, Gong J, Tan W, Bian B, Chen M, Wang Y: Fighting fire with fire: poisonous Chinese herbal medicine for cancer therapy. J Ethnopharmacol 2012, 140(1):33-45.

14. Fukai T, Satoh K, Nomura T, Sakagami H: Antinephritis and radical scavenging activity of prenylflavonoids. Fitoterapia 2003, 74(7-8):720-724.

15. Bottone FG Jr, Martinez JM, Alston-Mills B, Eling TE: Gene modulation by Cox-1 and Cox-2 specific inhibitors in human colorectal carcinoma cancer cells. Carcinogenesis 2004, 25(3):349-357.

16. Yan C, Lu D, Hai T, Boyd DD: Activating transcription factor 3, a stress sensor, activates p53 by blocking its ubiquitination. EMBO J 2005, 24(13):2425-2435

17. Wang $\mathrm{H}, \mathrm{Mo} \mathrm{P}$, Ren $\mathrm{S}$, Yan C: Activating transcription factor 3 activates p53 by preventing E6-associated protein from binding to E6. J Biol chem 2010, 285(17):13201-13210

18. Lu D, Wolfgang CD, Hai T: Activating transcription factor 3, a stress-inducible gene, suppresses Ras-stimulated tumorigenesis. J Biol chem 2006, 281(15):10473-10481.

19. Alao JP: The regulation of cyclin D1 degradation: roles in cancer development and the potential for therapeutic invention. Mole Cancer 2007, 6:24. 
20. Bahnassy AA, Zekri AR, El-Houssini S, El-Shehaby AM, Mahmoud MR, Abdallah S, El-Serafi M: Cyclin A and cyclin D1 as significant prognostic markers in colorectal cancer patients. BMC gastroenterol 2004, 4:22.

21. Banskota AH, Tezuka Y, Nguyen NT, Awale S, Nobukawa T, Kadota S: DPPH radical scavenging and nitric oxide inhibitory activities of the constituents from the wood of Taxus yunnanensis. Planta Med 2003, 69(6):500-505.

22. Nathan C: Nitric oxide as a secretory product of mammalian cells. FASEB $J$ 1992, 6(12):3051-3064.

23. Sung MJ, Davaatseren M, Kim W, Sung Kwang P, Kim SH, Haeng Jeon H, Myung Sunny K, Kim YS, Dae Young K: Vitisin A suppresses LPS-induced NO production by inhibiting ERK, p38, and NF-kappaB activation in RAW 264.7 cells. Int Immunopharmacol 2009, 9(3):319-323.

24. Jeong JB, Yang X, Clark R, Choi J, Baek SJ, Lee SH: A mechanistic study of the proapoptotic effect of tolfenamic acid: involvement of NF-kappaB activation. Carcinogenesis 2013, 34(10):2350-2360.

25. Kikuchi T, Nihei M, Nagai H, Fukushi H, Tabata K, Suzuki T, Akihisa T: Albanol A from the root bark of Morus alba L. induces apoptotic cell death in HL60 human leukemia cell line. Chem Pharm Bull 2010, 58(4):568-571.

26. Nam SY, Yi HK, Lee JC, Kim JC, Song CH, Park JW, Lee DY, Kim JS, Hwang $\mathrm{PH}$ : Cortex mori extract induces cancer cell apoptosis through inhibition of microtubule assembly. Arch Pharm Res 2002, 25(2):191-196.

27. Wang Q, Kuang H, Su Y, Sun Y, Feng J, Guo R, Chan K: Naturally derived anti-inflammatory compounds from Chinese medicinal plants. J Ethnopharmacol 2013, 146(1):9-39.

28. Sharma JN, Al-Omran A, Parvathy SS: Role of nitric oxide in inflammatory diseases. Inflammopharmacology 2007, 15(6):252-259.

29. Anggard E: Nitric oxide: mediator, murderer, and medicine. Lancet 1994 343(8907):1199-1206.

30. Lechner M, Lirk P, Rieder J: Inducible nitric oxide synthase (iNOS) in tumor biology: the two sides of the same coin. Semin Cancer Biol 2005, 15(4):277-289.

31. Chang H, Tsai SY, Chang Y, Chen TL, Chen RM: Therapeutic concentrations of propofol protects mouse macrophages from nitric oxide-induced cell death and apoptosis. Can J Anaesth 2002, 49(5):477-480

32. Hobbs AJ, Higgs A, Moncada S: Inhibition of nitric oxide synthase as a potential therapeutic target. Ann Rev Pharm Toxicol 1999, 39:191-220.

33. Marletta MA: Nitric oxide synthase structure and mechanism. J Biol Chem 1993, 268(17):12231-12234

34. Won JH, Kim JY, Yun KJ, Lee JH, Back NI, Chung HG, Chung SA, Jeong TS, Choi MS, Lee KT: Gigantol isolated from the whole plants of Cymbidium goeringii inhibits the LPS-induced iNOS and COX-2 expression via NF-kappaB inactivation in RAW 264.7 macrophages cells. Planta Med 2006, 72(13):1181-1187.

35. Lin CM, Huang ST, Liang YC, Lin MS, Shih CM, Chang YC, Chen TY, Chen CT: Isovitexin suppresses lipopolysaccharide-mediated inducible nitric oxide synthase through inhibition of NF-kappa B in mouse macrophages. Planta Med 2005, 71(8):748-753.

36. Ko HC, Kuo YH, Wei BL, Chiou WF: Laxifolone A suppresses LPS/IFNgamma-induced NO synthesis by attenuating NF-kappaB translocation: role of NF-kappaB p105 level. Planta Med 2005, 71(6):514-519.

37. Jin XY, Lee SH, Kim JY, Zhao YZ, Park EJ, Lee BS, Nan JX, Song KS, Ko G, Sohn $\mathrm{DH}$ : Polyozellin inhibits nitric oxide production by down-regulating LPS-induced activity of NF-kappaB and SAPK/JNK in RAW 264.7 cells. Planta Med 2006, 72(9):857-859.

38. Gilmore TD: Introduction to NF-kappaB: players, pathways, perspectives. Oncogene 2006, 25(51):6680-6684

39. Mankan AK, Lawless MW, Gray SG, Kelleher D, McManus R: NF-kappaB regulation: the nuclear response. J Cell Mol Med 2009, 13(4):631-643.

40. Sarkar FH, Li Y, Wang Z, Kong D: NF-kappaB signaling pathway and its therapeutic implications in human diseases. Int Rev Immunol 2008 27(5):293-319.

41. Surh YJ, Chun KS, Cha HH, Han SS, Keum YS, Park KK, Lee SS: Molecular mechanisms underlying chemopreventive activities of anti-inflammatory phytochemicals: down-regulation of COX- 2 and iNOS through suppression of NF-kappa B activation. Mutat Res 2001, 480-481:243-268.

42. Saxena A, Baliga MS, Ponemone V, Kaur K, Larsen B, Fletcher E, Greene J, Fayad R: Mucus and adiponectin deficiency: role in chronic inflammation-induced colon cancer. Int J Colorectal Dis 2013, 28(9):1267-1279.

43. Liang G, Wolfgang CD, Chen BP, Chen TH, Hai T: ATF3 gene. Genomic organization, promoter, and regulation. J Biol Chem 1996, 271(3):1695-1701.

44. Syed V, Mukherjee K, Lyons-Weiler J, Lau KM, Mashima T, Tsuruo T, Ho SM: Identification of ATF-3, caveolin-1, DLC-1, and NM23-H2 as putative antitumorigenic, progesterone-regulated genes for ovarian cancer cells by gene profiling. Oncogene 2005, 24(10):1774-1787.

45. Hartman MG, Lu D, Kim ML, Kociba GJ, Shukri T, Buteau J, Wang X, Frankel WL, Guttridge D, Prentki M, Grey ST, Ron D, Hai T: Role for activating transcription factor 3 in stress-induced beta-cell apoptosis. Mole Cell Biol 2004, 24(13):5721-5732.

46. Piyanuch R, Sukhthankar M, Wandee G, Baek SJ: Berberine, a natural isoquinoline alkaloid, induces NAG-1 and ATF3 expression in human colorectal cancer cells. Cancer Lett 2007, 258(2):230-240.

47. Lee SH, Yamaguchi K, Kim JS, Eling TE, Safe S, Park Y, Baek SJ: Conjugated linoleic acid stimulates an anti-tumorigenic protein NAG-1 in an isomer specific manner. Carcinogenesis 2006, 27(5):972-981.

48. Yan C, Jamaluddin MS, Aggarwal B, Myers J, Boyd DD: Gene expression profiling identifies activating transcription factor 3 as a novel contributor to the proapoptotic effect of curcumin. Mole Cancer Ther 2005, 4(2):233-241.

49. Lee SH, Min KW, Zhang X, Baek SJ: 3,3'-diindolylmethane induces activating transcription factor 3 (ATF3) via ATF4 in human colorectal cancer cells. Journal Nutr Biochem 2013, 24(4):664-671.

50. Kwon O, Soung NK, Thimmegowda NR, Jeong SJ, Jang JH, Moon DO, Chung JK, Lee KS, Kwon YT, Erikson RL, Ahn JS, Kim BY: Patulin induces colorectal cancer cells apoptosis through EGR-1 dependent ATF3 up-regulation. Cell Signal 2012, 24(4):943-950.

51. Casanovas O, Miro F, Estanyol JM, Itarte E, Agell N, Bachs O: Osmotic stress regulates the stability of cyclin D1 in a p38SAPK2-dependent manner. J Biol Chem 2000, 275(45):35091-35097.

52. Okabe H, Lee SH, Phuchareon J, Albertson DG, McCormick F, Tetsu O: A critical role for FBXW8 and MAPK in cyclin D1 degradation and cancer cell proliferation. PloS one 2006, 1:e128.

53. Diehl JA, Zindy F, Sherr CJ: Inhibition of cyclin D1 phosphorylation on threonine-286 prevents its rapid degradation via the ubiquitin-proteasome pathway. Genes Dev 1997, 11(8):957-972.

54. Lim JH, Lee YM, Chun YS, Park JW: Reactive oxygen species-mediated cyclin D1 degradation mediates tumor growth retardation in hypoxia, independently of p21cip1 and hypoxia-inducible factor. Cancer Sci 2008 , 99(9):1798-1805.

55. Cheon BS, Kim YH, Son KS, Chang HW, Kang SS, Kim HP: Effects of prenylated flavonoids and biflavonoids on lipopolysaccharide-induced nitric oxide production from the mouse macrophage cell line RAW 264.7. Planta Med 2000, 66(7):596-600.

56. Yang ZG, Matsuzaki K, Takamatsu S, Kitanaka S: Inhibitory effects of constituents from Morus alba var. multicaulis on differentiation of 3 T3-L1 cells and nitric oxide production in RAW264.7 cells. Molecules 2011, 16(7):6010-6022.

57. Lee JC, Won SJ, Chao CL, Wu FL, Liu HS, Ling P, Lin CN, Su CL: Morusin induces apoptosis and suppresses NF-kappaB activity in human colorectal cancer HT-29 cells. Biochem Biophys Res Co 2008, 372(1):236-242.

doi:10.1186/1472-6882-14-200

Cite this article as: Eo et al:: Anti-inflammatory and anti-cancer activity of mulberry (Morus alba L.) root bark. BMC Complementary and Alternative Medicine 2014 14:200.

\section{Submit your next manuscript to BioMed Central and take full advantage of:}

- Convenient online submission

- Thorough peer review

- No space constraints or color figure charges

- Immediate publication on acceptance

- Inclusion in PubMed, CAS, Scopus and Google Scholar

- Research which is freely available for redistribution 